\title{
SOME ASPECTS OF LEGAL REGULATION OF AGRICULTURAL PRODUCTS TRADE IN THE EU
}

\author{
Elen G. Martirosyan ${ }^{1}$
}

Abstract: This study deals with certain aspects of the common agricultural policy of the EU and considers some features of legal regulation of agricultural trade in the EU. Legal principles in regulating the organization of agricultural markets are highlighted; the system of intervention price and threshold price is analyzed. It is concluded that the prospects for the development of the agricultural market organization are described by certain economic indicators like production and consumption, exports and imports, acreage, etc. At the same time, there are legal factors that can significantly influence the legal aspects of agricultural trade in the European Union. For example, some of them are the system of mandatory compensation, new environmental standards, etc. A special place is occupied by the result of the reform of the agricultural sector: a system of one-time subsidies for farmers has been introduced.

Keywords: agricultural products, protocol, goods, price, compensation, environmental standards, subsidies, regulatory mechanism.

\section{Introduction}

The European Union has a stable mechanism for regulating and subsidizing the agricultural sector. Legal regulation in the field of agricultural trade in the EU is similar to American legislation. At the same time, a distinctive feature of European law in the agricultural sector is the priority of protectionist rules that promote the development of the sector over antimonopoly rules [1, Pp. 131-139]. The EU supports and encourages the necessary competition. Its main condition is to ensure the potential

\footnotetext{
${ }^{1}$ Moscow State Institute of International Relations (MGIMO University) Ministry of Foreign Affairs of the Russian Federation
} 
equality of forces of the parties involved in legal relations.

In the European Union, the general legal regulation of the agricultural market is aimed at improving the standard of living of the population, as well as optimizing the development of competitive agricultural production. This also implies financial support for agricultural producers, ensuring environmental protection, and the production of environmentally friendly goods [2, P. 300].

\section{Materials and methods}

The TFEU contains a set of legal principles for regulating the organization of agricultural markets. The most significant of them are:

- rejection and cancellation of any restrictions on trade in agricultural products between countries;

- ensuring the application of uniform prices for all types of agricultural products and mechanisms that stabilize them;

- ensuring protection of the domestic market from competitive products from third countries;

- financial support for agriculture from a single fund formed from contributions from member states.
732

Currently, the food market of agricultural crops is one of the most important, since these products are most in demand by both citizens and agricultural entrepreneurs [3, P. 515]. Their production is the most developed segment of the agricultural industry of the EU member btates [4]. Article 33 of the Treaty establishing the European Community states the objectives of the Community's activities in agriculture. In order to achieve them, article 34 of the Agreement provided for the creation of a common organizational mechanism for agricultural markets. For each food market, in addition to the general rules of regulation established by the provisions of the constituent agreements, there is also a special regulation that is implemented by applying the provisions of regulatory legal acts of secondary law.

\section{Materials and methods}

In agricultural legislation, the expression 'common market organization' is related to the unified legal structure of the Union, which provides for a set of instruments regulating the use of one or more groups of agricultural products on the common market. 
Professor Barents notes that the function of this organization is to 'achieve a state of integration' [5].

The Treaty on the Eurasian Economic Union [6] does not apply to agreements, decisions and practices in areas related to the production or trade of goods that form an integral part of the national market. As a result, article 101 of DFES does not cover contractual relations between farms, their associations and unions of these associations located on the territory of one member state of the Union and engaged in the sale of agricultural goods or using premises for their storage (processing), if this does not violate the principles of free competition.

In addition, by entering into agreements, farmers or their associations will also have to prove that this is the most rational means for the parties to achieve their goals and that there is no other way that less affects the provisions of antimonopoly law. The latter can cause certain difficulties [7, Pp. 480495].

It is also important in the context of this study that the European court of Justice [8] has given a restrictive interpretation of Regulation 26/62 to ensure the balance of domestic markets for agricultural goods: it only applies to the goods specified in Annex N 1 to the Agreement, and not to all agricultural products whose production is at least theoretically possible in the European community.

In addition, the remaining relevant articles of the TFEU fully apply to agricultural producers. For example, if abuse of a dominant position occurrs (article 102 of the TFEU), agricultural producers are liable on an equal basis with companies from other sectors.

Another significant document of the European Union in this study is the Resolution 2200/96 On the General organization of the market for fruit and vegetables [9].

One of its main goals is to support the direct purchasing by wholesalers and retailers from manufacturers without involving intermediaries.

This is facilitated by states creating specialized organizations with broad powers, namely:

- the right to intervene and regulate supply and demand in the domestic market of the country;

- transfer function in the area of farmers receiving state subsidies; 
- the right to withdraw a certain amount of goods from the market protecting the interests of national producers.

All rules and standards established by such organizations should be brought to the attention of the European Commission. If the Commission concludes on the definition of rules and standards that hinder, restrict or violate the principles of free competition, they would be adjusted.

\section{Discussion}

Turning to other features of legal regulation of trade in agricultural products in the European Union, this study considers the mechanism of legal regulation on the example of the general organization of trade in the grain market.

This direction is always relevant, since cereals are the most profitable products in agriculture. In law enforcement practice, the mechanisms of legal regulation of the general organization of the grain market include:

- price regulation systems;

- establishment of the procedure for state subsidies for products, their sale and storage;

- general tools to stabilize imports and exports.
According to Professor Asher, the general organization of the grain market acted as a support and example for the creation of other food markets [10].

Trade in agricultural products such as cereals is carried out using the guaranteed purchase price (intervention price) system. This system is a special legal means of regulating the general organization of the grain market. As a result of this approach, medium and large farms (holdings) have stable guarantees to get a certain level of income.

If the market price of a product falls to the level of the purchase price, special agents - public procurement organizations - buy this product until its price rises to the previous level. The purchase price defines a threshold below which the price cannot fall.

When purchasing grain intervention agencies are guided by the following principles:

- the system applies to products manufactured in the territory of the European Union;

- there is a principle of equal access of consumers to farmers' products. 
Interventional agents or member states acquire ownership of the purchased agricultural products, and the Union regulates interventional activities and subsequently reimburses them for their expenses.

The competent authorities of the European Union, limiting the glut of the domestic market with cheap imported goods, also use the threshold price. This is the minimum price, and imported products can be sold on the market at this price. It is higher than the intervention price, which encourages market participants to buy products that are produced in the European Union. As a result, the basic principle of EU agricultural law (that is, the preferences for farmers of the Union) is observed. The threshold price is calculatedas follows: its size is equal to the target price with the deduction of transportation costs from the main point of import of products to the main place of consumption. As noted by the scientists A. Lissitsa, O. Luca, T. Gagalyuk, S. Kvashi, the function of this price in the process of optimizing the mechanism of legal regulation of agricultural production is that it acts as the basis for calculating the import tariff, which is defined as the difference between the threshold and the world price (including insurance and freight costs, i.e. the CIF price), at which goods are imported into the territory of the European Union [11].

However, it is not possible to fully protect the EU internal market from cheap products from third countries with just one threshold price. In this regard, the European Union has established a compensation fee for imported grain products. The amount of fees is defined as the difference between the threshold price and the CIF price. When setting the CIF price, changes in world grain prices should also be considered. It increases with the growth of world prices, and at the same time the amount of the compensation fee decreases. So, the lower is the price of grain offered by the supplier, the greater is the amount of the fee they should be paid. Calculating the amount of compensation fee and CIF price, the special Commission of the European Union takes as a basis the lowest price of supply on the grain market.

Currently, one of the main legal acts regulating the grain market in the European Union is Council Regulation $1784 / 2003$ on the general organization of the grain market [12, P. 300], which has 
replaced the former Regulation 1766/92. Professor Barling's research reveals the term 'market organization' in relation to the legal regulation of the grain food market. In a broad sense, it should be understood as 'price stabilization by the introduction of a financial assistance program and the establishment of detailed rules in the field of trade with third countries' [12, P. 332].

The provisions of this act are applied without prejudice to the measures of Council Regulation $1782 / 2003$, which sets out the general rules for the support for agricultural programmes, as well as for farmers' support programmes. Regulation is based on the mechanisms of intervention and the general system of import and export, which, according to Professor Asher, acts as the 'core of the general organization of the grain market' $[10, \mathrm{P}$. 53].

The preamble of this Regulation states that the creation of a single market for grain crops includes the introduction of trade systems at the external borders of the Union. This system, based on agreements adopted during the Uruguay round of GATT-WTO multilateral trade negotiations, complements intervention mechanisms and includes import duties and export subsidies, thereby stabilizing the overall situation in the EU internal market. The Regulation defines grain products as all types of grain crops (corn, barley, plain and durum wheat, malt, rye, etc.).

Starting from July 1 of each year, the trading year is set in this context. Regulations on cereals set the purchase price per ton of products, but this price is not final and fixed.

From November to June next year, the price may change. The procurement of products by intervention agencies is carried out in strict compliance with certain deadlines and in relation to specific EU member States. Based on this, one can refer to the Commission's Regulation 2273/1992 that establishes the basis for the legal regulation of the functioning of intervention centers for the purchase of grain crops [13, P. 30-37].

The purpose of this act is to 'ensure the proper functioning of the whole intervention system'. It is necessary to note that according to the Regulations, each intervention center and warehouse should meet certain conditions, namely:

- it should be located in a region growing a large number of grain crops, 
where regional demand is significantly exceeded (the intervention center should have a warehouse with appropriate equipment that would provide the possibility of receiving, loading and unloading a large number of products);

- it should have an area that allows storing a large quantity of products.

The system of tariff quotas for cereals is described by certain legal features. The European Commission applies one of the following methods, or combine them:

1) a method that is based on the chronological order of applications, based on the principle of 'first arrived, first processed';

2) the method of proportional distribution based on the number of applications submitted (synchronous verification method);

3) a method based on traditional trade patterns (traditional method).

Other methods can also be applied, but they should not allow unjustified discrimination against agricultural producers. In the process of establishing quotas, the detailed rules are applied, and they determine the choice of an administrative method of regulation.
The following guarantees are also taken into account when choosing:

- guarantees that cover the nature and origin of the product;

- recognition of the document that is used to confirm the above mentioned guarantees;

- conditions under which the import licenses are issued and their validity period.

In addition to the general rules for the export of agricultural products, the implementation of its legal regulation has certain features.

Thus, the legal basis for these types of activities is Commission Regulation 1342/2003, which establishes detailed rules for the application of the system of export and import of grain crops [14, P. 70].

Regulation indicates the ability to conduct tenders and auctions to obtain a permit for the export of food from the intervention stocks.

In this case, the license determine both the volume and destination of exported products. The validity periods of import and export licenses are determined specially for different products. The criterion in this issue is market demand, as well as the need for good management. When issuing 
licenses for the export of grain crops in large quantities, there is a certain risk that the applicant will exceed their authority. In this regard, the competent authorities set a break for 3 days before the actual issuance of licenses. This rule does not apply to non-commercial food aid exports.

In cases where the Commission's decision not to grant a license violates the continuity in the regular supply of goods, operators can obtain an export license without compensation under special conditions of use.

\section{Results}

The mechanism of legal regulation of the agricultural grain market is a system that supports producers of certain types of grain crops. Its main function is to optimize operations and stabilize the market for a specific product type. Its legal basis is Council Regulation 1782/2003, which sets out the general rules for direct support programs within the framework of the unified agricultural policy and direct support programs for farmers, as well as a number of additional regulations [15, P. 73]. The single payment program, which is provided for in the regulations, acts as a guarantee that farmers will receive their income.

\section{Conclusion}

The conclusion is as follows:

basically, the prospects for the development of the agricultural market organization in the European Union are described by economic indicators (production and consumption volumes, export and import volumes, acreage, etc.). At the same time, there are legal factors that can significantly influence the legal aspects of agricultural trade in the European Union (for example, the system of mandatory compensation, new environmental standards, system of granted subsidies for farmers).

\section{References}

Voronina M.A. Istoki agrarnoj integracii stran Evropejskogo soyuza // V sbornike: Sovremennye problemy geografii Mezhvuzovskij sbornik nauchnyh trudov. Sostaviteli V.V. Zanozin, M.M. Iolin, A.N. Barmin, A.Z. Karabaeva, M.V. Valov. Astrahan', 2019. S. 198203. [Voronina M.A. The origins of agrarian integration of the countries of the European Union // In the collection: Modern problems of geography 
Interuniversity collection of scientific papers. Compiled by V.V. Zanozin, M.M. Iolin, A.N. Barmin, A.Z. Karabaeva, M.V. Valov. Astrakhan, 2019. P. 198-203.]

Dolgih O.S., Novikova T.V., Dedkova E.V. Prodovol'stvennoe zakonodatel'stvo v stranah ES: celi i principy // Vestnik Altajskoj akademii ekonomiki i prava. 2020. № 3-2. S. 201209. [Dolgikh OS, Novikova TV, Dedkova EV Food legislation in the EU: goals and principles // Bulletin of the Altai Academy of Economics and Law. 2020. No. 3-2. P. 201-209.]

Dyusyupova A.D. Sovremennoe sostoyanie pravovogo regulirovaniya agrarnoj politiki v gosudarstvah-chlenah Evrazijskogo ekonomicheskogo soyuza // Agrarnoe i zemel'noe pravo. 2019. № 6 (174). S. 88-93. [Dyusyupova A.D. The current state of the legal regulation of agricultural policy in the member states of the Eurasian Economic Union // Agricultural and land law. 2019.No 6 (174). P. 88-93.]

Kiselyova V.I. Problemy i perspektivy razvitiya torgovli sel'skohozyajstvennoj produkciej mezhdu Rossiej i ES // V sbornike: Marketing i logistika v sisteme konkurentosposobnogo biznesa. IV
Nauchno-prakticheskaya konferenciya molodyh uchenyh, aspirantov, studentov. 2019. S. 25-27. [Kiseleva V.I. Problems and prospects for the development of agricultural trade between Russia and the EU // In the collection: Marketing and logistics in the system of competitive business. IV Scientific-practical conference of young scientists, graduate students, students. 2019.P. 25-27.]

Marchenko M.N., Deryabina E.M. Pravovaya sistema Evropejskogo soyuza: monografiya. M.: Norma, InfraM, 2012. 704 s. [Marchenko M.N., Deryabin E.M. European Union Legal System: Monograph. M .: Norma, InfraM, 2012.704 p.]

$\begin{array}{lll}\text { Sushko } & \text { V.I. } & \text { Edinaya }\end{array}$ sel'skohozyajstvennaya politika kak faktor uspeshnogo razvitiya prodovol'stvennogo rynka ES // Ekonomika. Biznes. Finansy. 2019. № 11. S. 34-39. [Sushko V.I. Unified agricultural policy as a factor in the successful development of the EU food market // Economics. Business. Finance. 2019.No 11.P. 34-39.]

Agriculture: financial aspects // https://ec.europa.eu/info/sites/info/files/ food-farming-

fisheries/farming/documents/agri- 
statistical-factsheet-eu_en.pdf

(Data

obrashcheniya: 19.05.2020 g.)

Council Regulation (EC) No 2200/96 of

28 October 1996 on the common organization of the market in fruit and vegetables // https://eurlex.europa.eu/legal-

content/en/ALL/?uri=CELEX\%3A3199 6R2200(Data obrashcheniya: 18.05.2020 g.)

Council Regulation (EC) No 1784/2003 of 29 September 2003 on the common organisation of the market in cereals // https://www.mof.gov.cy/mof/customs/c ustoms.nsf/All/9E6A35CFBCC0CFF1C 225730D001FE4D4/\$file/1784-

2003.pdf?OpenElement

(Data

obrashcheniya: 18.05.2020 g.)

Eurostat Statistics Explained // https://ec.europa.eu/eurostat/statisticsexplained/index.php/Main_Page (Data obrashcheniya: 18.05. 2020 g.).

EU balance sheet // European Commission:

https://ec.europa.eu/info/food-farming-

fisheries/farming/facts-and-

figures/markets/overviews/balance-

sheets-sector_en. (Data obrashcheniya: 19.05.2020 g.)

Regulation (EU) No 1307/2013 of the European Parliament and of the Council of 17 December 2013 establishing rules for direct payments to farmers under support schemes within the framework of the common agricultural policy and repealing Council Regulation (EC) // http://data.europa.eu/eli/reg/2013/1307/ oj (Data obrashcheniya: 18.05.2020 g.) Regulation (EU) No 1308/2013 of the European Parliament and of the Council of 17 December 2013 establishing a common organisation of the markets in agricultural products and repealing Council Regulations (EEC) // http://data.europa.eu/eli/reg/2013/1308/ oj (Data obrashcheniya: 18.05.2020 g.) 14. Regulation (EU) No 1306/2013 of the European Parliament and of the Council of 17 December 2013 on the financing, management and monitoring of the common agricultural policy and repealing Council Regulations (EEC) // http://data.europa.eu/eli/reg/2013/1306/ oj (Data obrashcheniya: 18.05.2020 g.) Regulation (EU) No 1305/2013 of the European Parliament and of the Council of 17 December 2013 on support for rural development by the European Agricultural Fund for Rural Development (EAFRD) and repealing Council Regulation (EC) // http://data.europa.eu/eli/reg/2013/1305/ oj (Data obrashcheniya: 18.05.2020 g.) 
Mansholt S. On the threshold of a common agricultural policy // https://www.cvce.eu/en/obj/sicco_mans holt_on_the_threshold_of_a_common_a gricultural_policy-en.html_(Data obrashcheniya: 18.05.2020 g.)

Treaty of Rome (EEC) // https://eurlex.europa.eu/legalcontent/EN/TXT/?uri=LEGISSUM\%3A xy0023 (Data obrashcheniya: 18.05.2020 g.)

Treaty on the Functioning of the European Union, TFEU // http://data.europa.eu/eli/treaty/tfeu_201 2/oj (Data obrashcheniya: 18.05.2020 g.) Treaty establishing the European Community (Consolidated version 2002) //

http://data.europa.eu/eli/treaty/tec_2002 /oj (Data obrashcheniya: 18.05.2020 g.) Usher J.A. Litigating in Luxembourg and the Role of the Advocate at the Court of Justice, in Continuity and Change in EU Law. 48 Oxford University Press, 2008. P. 51 - 54 